\title{
The impact of polytechnic institutes on the local economy
}

João Alves, Luísa Carvalho, Renato Carvalho, Florbela Correia, Jorge Cunha, Luís Farinha, Joana Fernandes, Manuela Ferreira, Eugénio Lucas, Joaquim Mourato, Ana Nicolau, Sara Nunes, Sandra Nunes, Pedro Oliveira, Cristina Pereira, Sandra Pinto \& José Silva

To cite this article: João Alves, Luísa Carvalho, Renato Carvalho, Florbela Correia, Jorge Cunha, Luís Farinha, Joana Fernandes, Manuela Ferreira, Eugénio Lucas, Joaquim Mourato, Ana Nicolau, Sara Nunes, Sandra Nunes, Pedro Oliveira, Cristina Pereira, Sandra Pinto \& José Silva (2015) The impact of polytechnic institutes on the local economy, Tertiary Education and Management, 21:2, 81-98, DOI: $10.1080 / 13583883.2014 .999110$

To link to this article: https://doi.org/10.1080/13583883.2014.999110

册 Published online: 19 Feb 2015.

Submit your article to this journal $₫$

Џ Article views: 190

Q View related articles $\sqsubset$

View Crossmark data $־$

Citing articles: 1 View citing articles ๘ 


\section{The impact of polytechnic institutes on the local economy}

João Alves ${ }^{\mathrm{a}}$, Luísa Carvalho ${ }^{\mathrm{b}}$, Renato Carvalho ${ }^{\mathrm{c}}$, Florbela Correia ${ }^{\mathrm{d}}$, Jorge Cunha ${ }^{\mathrm{e}}$, Luís Farinha $^{\mathrm{f}}$, Joana Fernandes ${ }^{\mathrm{g}}$, Manuela Ferreira ${ }^{\mathrm{h}}$, Eugénio Lucas ${ }^{\mathrm{i}}$, Joaquim Mourato ${ }^{\mathrm{a}}$, Ana Nicolau ${ }^{\mathrm{i}}$, Sara Nunes ${ }^{\mathrm{j}}$, Sandra Nunes ${ }^{\mathrm{k}}$, Pedro Oliveira ${ }^{\mathrm{l}}$, Cristina Pereira ${ }^{\mathrm{a}}$, Sandra Pinto ${ }^{\mathrm{m}}$ and José Silva ${ }^{\mathrm{i}}$

${ }^{a}$ C3i, Instituto Politécnico de Portalegre, Portalegre, Portugal; ${ }^{b}$ Departamento de Ciências Sociais e de Gestão, Universidade Aberta, Lisbon, Portugal; ${ }^{c}$ CI\&DETS - Centro de Estudos em Educação, Tecnologias e Saúde, Instituto Politécnico de Viseu, Viseu, Portugal; ' Instituto Politécnico de Viana do Castelo, Viana do Castelo, Portugal; ${ }^{e}$ Departamento de Produção e Sistemas, Universidade do Minho, Guimarães, Portugal; ${ }^{f}$ Escola Superior de Tecnologia, Instituto Politécnico de Castelo Branco, Castelo Branco, Portugal; ${ }^{g}$ Escola Superior de Comunicção, Administração e Turismo, Instituto Politécnico de Bragança, Bragança, Portugal; ${ }^{h}$ Escola de Saúde, Instituto Politécnico de Viseu, Viseu, Portugal; ${ }^{i}$ CIPSE - Centro de Investigação em Políticas e Sistemas Educativos, Instituto Politécnico de Leiria, Leiria, Portugal; ${ }^{j}$ Escola Superior de Gestão, Instituto Politécnico de Castelo Branco, Castelo Branco, Portugal; ${ }^{k}$ Departamento de Economia e Gestão, Escola Superior de Ciências Empresariais, Instituto Politécnico de Setúbal, Setúbal, Portugal, ${ }^{l}$ ICBAS - Instituto de Ciências Biomédicas Abel Salazar, Universidade do Porto, Porto, Portugal; ${ }^{m}$ Unidade de Apoio à Inovação, I\&D e Empreendedorismo, Instituto Politécnico de Setúbal, Setúbal, Portugal

(Received 5 June 2014; accepted 10 December 2014)

Higher education institutions and, particularly, polytechnic institutes in Portugal are, generally speaking, recognized as the key stakeholders in regional development. However, due to the economic recession of recent years and the consequent budget constraints, higher education institutions more than ever need to demonstrate the social and cultural impact of their activities within their communities and their contribution to its economic development. The aim of this paper is to estimate the economic impact of a group of polytechnic institutes located in regions with diverse socio-economic characteristics using a common methodology. This common framework enables a comparative study and a better identification of the variables that differentiate the different regions, the respective polytechnics and their impacts.

Keywords: higher education policy/development; inclusive/exclusive higher education; national systems of higher education

\section{Introduction}

In 2012, following a study on the economic impact of the Polytechnic Institute of Bragança (Fernandes, 2009; Fernandes, Cunha, \& Oliveira, 2013), similar studies were carried out at other institutes, with the support of the Portuguese Polytechnics Coordinating Council. The aim was to assess how the different institutes impact their respective regions, according to a common methodology, which would therefore allow a comparison between such diverse realities. It should be noted that the aim is not to produce a ranking of polytechnic institutes, but to understand how their impact may be

\footnotetext{
*Corresponding author. Email: pnoliveira@icbas.up.pt
} 


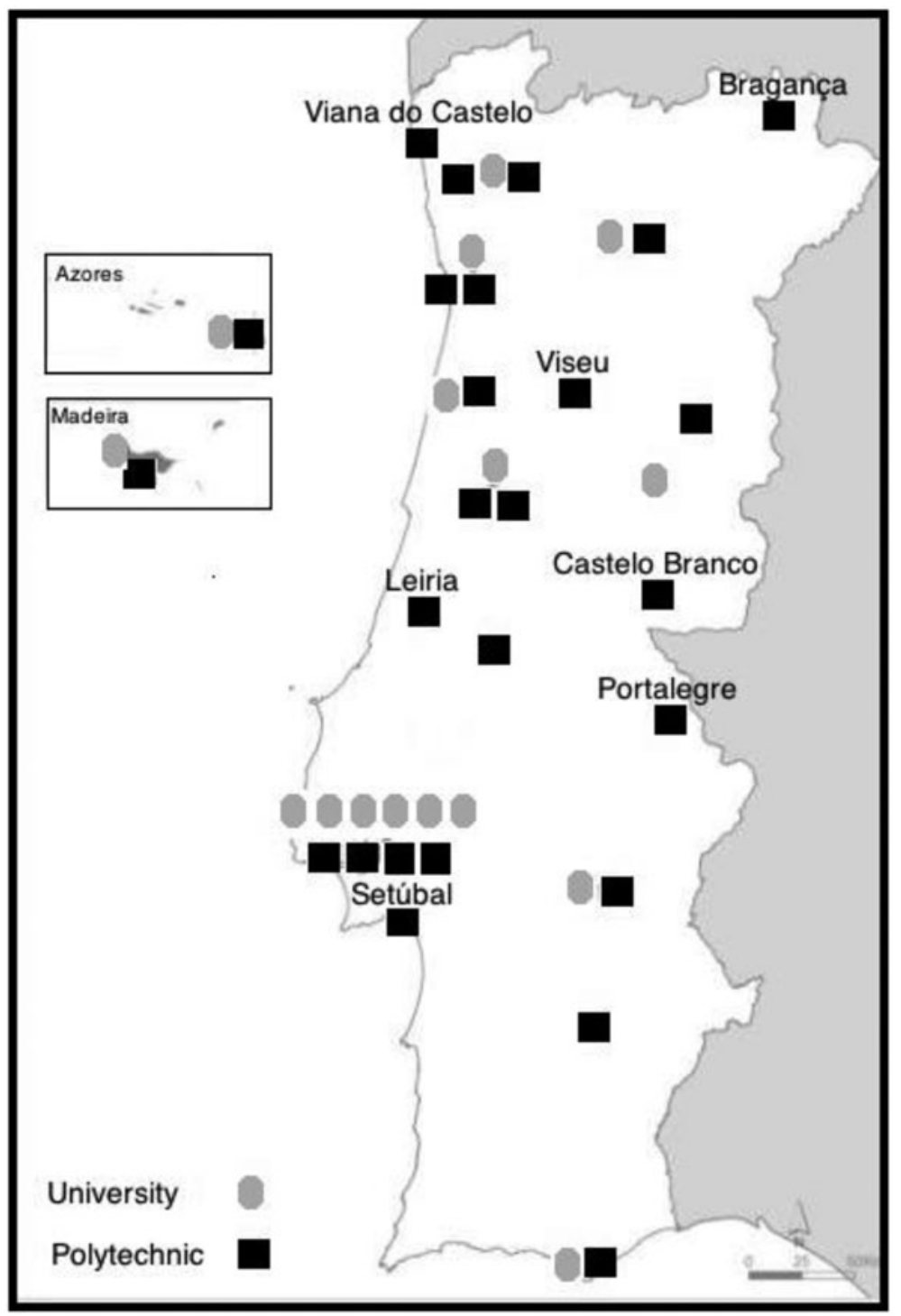

Figure 1. Distribution of public higher education institutions in Portugal (universities and polytechnics).

Source: A3ES (2012).

different, depending on their region and on the characteristics of each institute in terms of student population. Given the difficulties of carrying out a comprehensive and simultaneous study of all polytechnic institutes, seven institutes were selected (see Figure 1): three located in coastal regions (Viana do Castelo, Leiria and Setúbal) and four in inner regions (Bragança, Viseu, Castelo Branco and Portalegre). These institutes cover diverse regions - from coastal, industrialized areas to less-developed rural regions, detached from great urban centres, as well as areas that are geographically classified as coastal but whose indicators are typical of those found in inner regions. In this first phase, institutes located 
in large cities were intentionally not considered, as their assessment poses methodological difficulties due to the proximity of university institutions within the same cities.

The aim of this work is to assess and understand how the presence of a polytechnic institute in a given region contributes towards its social and economic development and, furthermore, to understand the impact of such institutions in different contexts, varying in terms of population size, age structure, literacy, purchasing power, economic activity and geographic location.

\section{The evolution of the higher education system and economic impact studies}

The Portuguese higher education system has experienced severe changes over the last four decades. In 1974, when dictatorship took its last breath and the current democratic regime was established, there were only three public universities, with approximately 86,000 students. In 2006/2007, there were - in the public sector - 16 universities ( 7 of which integrated polytechnic schools in areas such as accounting and nursing), 15 polytechnic institutes and 5 non-integrated, specialized polytechnic schools (offering courses in areas such as nursing, tourism and maritime activities) (Agência de Avaliação e Acreditação do Ensino Superior [A3ES], 2012), in a total of 121 higher education institutions with, approximately, 360,000 students and 37,000 teachers (Organisation for Economic Co-operation and Development [OECD], 2008). In 2012, the number of students reached 390,000 and $80 \%$ of them were in the public higher education system (Center for Higher Education Policy Studies [CHEPS], 2013; Instituto Nacional de Estatística [INE], 2012 (http://www.ine.pt/); OECD, 2012). The strong growth in access to higher education between 1974 and 2000, at a rate of $6 \%$ per year, was accompanied by the creation of higher education institutions all over the country. It is particularly relevant that, while the university subsystem is mostly distributed along the Portuguese coastal region, the polytechnic subsystem was, from the very beginning, intended to ensure a wider territorial coverage, which undoubtedly constitutes a key factor for equality in access to higher education (see Figure 1).

In 1974, the percentage of youths aged 18-24 enroled in higher education was around $8 \%$, reaching around $48 \%$ in 2012 . However, Portugal remains far below the average of its European counterparts in terms of both secondary and higher education graduates (see Table 1). In 2010, the percentage of the Portuguese population who had graduated from tertiary education, within the 25-64 age group, was $15 \%$, whereas for Europe (UE-21), this percentage was 28\% (OECD, 2012) (see Table 2).

Tables 1 and 2 clearly show that despite the huge efforts that Portugal has dedicated to education, and its clear progress, other countries were equally industrious and, therefore, the gap that separates Portugal from the European average is still quite significant.

A topic that has emerged recently within Portuguese society, as a result of the economic crisis and budget constraints, is the assessment of the economic impact of higher

Table 1. Percentage of the population with at least a secondary education.

\begin{tabular}{llllll}
\hline & $25-64$ & $25-34$ & $35-44$ & $45-54$ & $55-64$ \\
\hline Portugal & 32 & 52 & 34 & 22 & 16 \\
EU21 & 75 & 83 & 80 & 73 & 64 \\
\hline
\end{tabular}

Source: OECD (2012).

Note: EU21 - Austria, Belgium, Czech Republic, Denmark, Estonia, Finland, France, Germany, Greece, Hungary, Ireland, Italy, Luxembourg, the Netherlands, Poland, Portugal, Slovakia, Slovenia, Spain, Sweden and the UK. 
Table 2. Percentage of the population graduated from higher education.

\begin{tabular}{lccccc}
\hline & $25-64$ & $25-34$ & $35-44$ & $45-54$ & $55-64$ \\
\hline Portugal & 15 & 25 & 16 & 10 & 9 \\
EU21 & 28 & 35 & 30 & 25 & 20 \\
\hline
\end{tabular}

Source: OECD (2012).

Note: EU21 - Austria, Belgium, Czech Republic, Denmark, Estonia, Finland, France, Germany, Greece, Hungary, Ireland, Italy, Luxembourg, the Netherlands, Poland, Portugal, Slovakia, Slovenia, Spain, Sweden and the UK.

education institutions on their respective regions. Evidence seems to show (e.g. Arbo \& Benneworth, 2007; Hermannsson \& Swales, 2010; Lawton-Smith, 2003) that higher education institutions are important mechanisms for regional development, which create educational and cultural opportunities that would not exist in these regions without these institutions (Charney \& Pavlakovich-Kochi, 2003; Smith, 2006).

The assessment of the regional impact followed two approaches. One of the approaches is based on the estimation of the economic impact (Drucker \& Goldstein, 2007; Siegfried, Sanderson, \& McHenry, 2007), reflected, for instance, in increased economic activity, numbers of jobs and income levels (Yserte \& Rivera, 2010), in the higher qualification of the active population and in workers' productivity (Becker, 1993; Bluestone, 1993), or in research and development activities and technology transfer (Rephann, Knapp, \& Shobe, 2009).

The other approach adopts a more global perspective and employs cost-benefit analysis, by including not only individual benefits but also social benefits - externalities which emerge in society as a result of the existence of a higher education institution in a given region. There is a wide range of non-monetary impacts on local economy that must be taken into consideration (Hermannsson \& Swales, 2010). The presence of a higher education institution may bring public (e.g. more taxes and more leases) and private (e.g. better salaries and better jobs) economic benefits, as well as public (e.g. decreased unemployment rate, reduction in poverty and criminality, and reduced welfare dependency) and private (e.g. greater life expectancy, greater satisfaction at the workplace, better quality of life, improved health and greater family stability) social benefits, despite the likelihood of some costs being incurred (e.g. land use and tax exemptions).

The integration of an institute into a region may constitute a contribution in the form of the development of local networks that promote a good learning environment and the improvement of skills, capabilities and qualifications, as well as increased competitiveness and social cohesion (Boucher, Conway, \& Van der Meer, 2003). Given that polytechnics are complex organisations with different activities and communities (Pinheiro, Benneworth, \& Jones, 2012), and given the existence of different mechanisms by which the involvement of the institutions may be reviewed (Benneworth, Charles, Hodgson, \& Humphrey, 2013), this paper focuses on a particular dimension - measuring the economic impact of a polytechnic institution on a given region.

\section{The Portuguese polytechnic system}

Over the last few decades, the Portuguese higher education system has undergone deep changes. As in other European countries, in the 1980s, a polytechnic network was created, thus introducing a binary system.

In the early 1970s, international organisations, such as the OECD, highlighted the importance of developing and enlarging the medium and higher cadres in Portugal, so that they would be able to meet the needs of ongoing social and economic development, 
namely graduates with shorter but highly professionalised training, conducive to the exercise of technical professions.

There is wide consensus around the importance of higher education as a promoter of social and economic development, especially at a regional level (Arbo \& Benneworth, 2007; Charles, 2006; Etzkowitz \& Leydesdorff, 2000; Mueller, 2005). It was based on the assumption that they would constitute regional development agents that polytechnic institutes were created, and their mission would be to develop more reproducible applied research, with significant repercussions on economic and social development, thus playing an important role in the less-developed regions located throughout the inner strip of the country.

The polytechnic institute network is well distributed across the entire country (see Figure 1), reaching less-developed regions and, for that reason, constituting a powerful mechanism to promote equity in access to higher education, in addition to the economic benefits. The highest percentage of the Portuguese population is concentrated along the coastal area, so institutes located further inland contribute to the improvement of those less-developed regions, as they constitute both a factor of attraction and a factor of fixation of the population.

Table 3 presents a brief characterization of the seven polytechnic institutes studied (see Figure 1), including number of students, staff (administrative and technical employees) and faculty (academics), and percentage of academics who hold a PhD.

Table 4 shows the population and the rates (lower and upper limits) of illiteracy, ageing population and purchasing power for the municipalities where the seven

Table 3. Characterization of polytechnic institutes - students, staff and faculty.

\begin{tabular}{lccrc}
\hline Institute & Faculty & Staff & Students & $\%$ PhD \\
\hline Bragança & 449 & 214 & 6754 & 38 \\
Castelo Branco & 374 & 259 & 4582 & 35 \\
Leiria & 980 & 310 & 12,102 & 31 \\
Portalegre & 210 & 165 & 2542 & 28 \\
Setúbal & 608 & 166 & 6730 & 23 \\
Viana do Castelo & 340 & 172 & 4276 & 35 \\
Viseu & 438 & 266 & 6407 & 26 \\
\hline
\end{tabular}

Note: Reference year 2012 .

Table 4. Some indicators of the seven municipalities where the chosen polytechnic institutes are located.

\begin{tabular}{|c|c|c|c|c|}
\hline Institute & Inhabitants $^{\mathrm{a}}$ & Illiteracy $^{\mathrm{b}}$ & Ageing $^{c}$ & $\begin{array}{l}\text { Purchasing } \\
\text { power }^{\mathrm{d}}\end{array}$ \\
\hline Bragança & 59,191 & $7.9-9.0$ & $181-208$ & $80-96$ \\
\hline Castelo Branco & 65,825 & $7.0-20.6$ & $188-494$ & $61-95$ \\
\hline Leiria & 206,379 & $4.7-6.0$ & $113-139$ & $86-103$ \\
\hline Portalegre & 48,008 & $7.7-8.2$ & $144-180$ & $85-102$ \\
\hline Setúbal & 199,949 & $7.8-8.8$ & $112-152$ & $100-107$ \\
\hline Viana do Castelo & 155,563 & $4.4-9.5$ & $130-389$ & $62-93$ \\
\hline Viseu & 125,965 & $5.4-7.6$ & $122-145$ & 79-96 \\
\hline
\end{tabular}

Notes: ${ }^{\text {a }}$ Total number of inhabitants of each municipality where the polytechnic institute has schools.

${ }^{b}$ Percentage of people aged 10 or older who cannot read or write.

${ }^{\mathrm{c}}$ Ratio between the number of people aged 65 or older, and the number of people aged $0-14$.

${ }^{\mathrm{d}}$ National average equal to 100 .

Source: INE - Reference year: 2011. 
institutes are located (minimum and maximum values for the municipalities of each institute). These indicators, among others, show how the characteristics of the regions make the presence of the institutes ever more important.

Table 4 shows that, generally speaking, illiteracy and ageing population levels are higher in municipalities located in rural areas, which also have lower purchasing power and lower populations. Some institutes are located in regions that cover municipalities with very diverse indicators, so the analysis can be somewhat biased by a simplistic division between coastal and rural areas.

\section{Economic impact}

An economic impact study aims at estimating the increase in the level of economic activity within a given region as a result of the presence of a higher education institution (Elliott, Levin, \& Meisel, 1988). Therefore, the contribution of a polytechnic institute to the local economy might be measured based on its impact on the levels of economic activity of that region, with positive effects on local employment and income levels. It is known that a significant portion of the revenue generated in local economies comes from sources that are external to those regions, but that are directly associated with them. Given the approach adopted in this study (known in the literature as a demand-side approach, Brown \& Heaney, 1997), the economic impact of a higher education institution can be estimated by considering three kinds of effects (Yserte \& Rivera, 2010): direct, indirect and induced economic effects.

Direct effects correspond to the direct spending of the faculty, staff, students and also of the institution itself on local goods and services. For this estimate, a conservative perspective was adopted: for example, in the case of students, it only included the spending of students who had moved to the region to study at the polytechnic (the export effect), as well as that of local students who would be studying at another higher education institution outside the region, should this polytechnic not exist (the import substitution effect).

The indirect and induced economic effects correspond to the impacts on the supply chain of the economic sector whose activity is being considered for direct effects and changes in consumer spending as a result of the variation in the number of jobs and income generated in the local economy. In other words, they represent the propagation of the impact caused by the initial spending throughout the local economy.

Since the latter two effects are difficult to estimate, several authors have chosen to apply a multiplier value. For example, Ryan and Malgieri (1992) consider that this value depends on the size of the region under analysis. An ever-controversial topic in economic impact analysis is the definition of an appropriate geographic area to be considered in the study (Siegfried et al., 2007). The main reason is that - depending on how geographic area is defined - specific economic effects will be felt within and outside the region (Elliott et al., 1988), thus determining the multiplier value to use.

For example, MacFarland (1999) considers that when the study is confined to a relatively small geographical area, a conservative multiplier should be used (1.8-2.2), because the proportion of the first round of spending that will leave the area immediately will be greater, that is, a small region tends to purchase a larger proportion of its inputs from other regions. On the other hand, for a larger geographical area, a higher multiplier should be used (2.4-3.0).

Thus, in this study, a multiplier of 1.7 was used. It was determined from the median of the various multipliers used in several studies (see Table 5) and falls within the range 
Table 5. Multiplier values used in several studies.

\begin{tabular}{ll}
\hline Author & Multiplier \\
\hline Anton and Burns (2007) & Income: 1.825 \\
Bluestone (1993) & Income: 1.341 \\
Caleiro and Rego (2003) & Income: $[1.2 ; 1.3]$ \\
Carr and Roessner (2002), Smith (2006) & Income: 2.0 \\
Clarck, Feng, and Stromsdorfer (1998) & Income: 1.4 \\
Duhart (2002) & Income: 1.6 \\
Emmett and Manaloor (2000) & Employment: 2.49 \\
Healey and Akerblom (2003), Livingston (2001), Ohme & Income: 1.8 \\
$\quad$ (2004) & \\
Jefferson College (2003), Seybert (2003) & Income: 1.9 \\
Langworthy (2001) & Income: 1.58 \\
MacFarland (2001) & Income: $[1.8-3.0]$ with a 2.0 mean \\
McNicoll, McCluskey, and Kelly (1997) & Income: 3.21 \\
Miller (1994) & Income: $[1.0 ; 3.0]$ \\
Nagowski (2006) & Income: $[1.8 ; 3.1]$ \\
Ryan and Malgieri (1992) & Income: $[1.2-3.0]$ with a 1.9 mean \\
Siegfried et al. (2007) & Income: $[1.34 ; 2.54]$ with a 1.7 median \\
& Employment: [1.32; 4.75$]$ with a 1.8 \\
Sudmant (2002) & median \\
University of Strathclyde (2006) & Income: 1.5 \\
Yserte and Rivera (2010) & Income: 2.52 \\
\hline
\end{tabular}

reported by Weisbrod and Weisbrod (1997). Indeed, these authors argue that the values of the multipliers to be used in most industries are usually around 2.5-3.5 where the geographical area of impact is nationwide; 2.0-2.5 when measuring the impact at state level; and 1.5-2.0 for local studies.

Figure 2 shows the economic model used in this study. This model allows for the calculation of the export effect and the import substitution effect.

This model's design is derived from Caffrey and Isaacs' (1971) American Council on Education (ACE) model. During the application of the ACE model by Fernandes (2009), there were several aspects that made its application rather difficult; among other aspects, that either not all the required information is available, or it requires a significant amount of time and resources to collect the information needed on an annual basis. Caffrey and Isaacs (1971) included in their calculations all students attending higher education institutions, without considering that only students coming from other regions introduce new inputs into the region where the higher education institution is located, which can distort the analysis carried out. Thus, only students who have moved from their original region to attend the polytechnic should be considered as impacts of the institution (the export effect). Moreover, some authors (e.g. Blackwell, Cobb, \& Weinberg, 2002; Elliott et al., 1988; Humphreys \& Kamerschen, 2001; Johnson, 1994; Smith, 2006), argue that local students who would have left the region to study elsewhere, should the polytechnic not exist, also represent an impact originated by the existence of the polytechnic; otherwise, their spending would have taken place in another region (the import substitution effect).

Considering the difficulties encountered and the results obtained by applying the ACE model, Fernandes (2009) proposed a simplified version of that model, adapted to the Portuguese reality, which allows a fairly accurate approximation to the impact of 


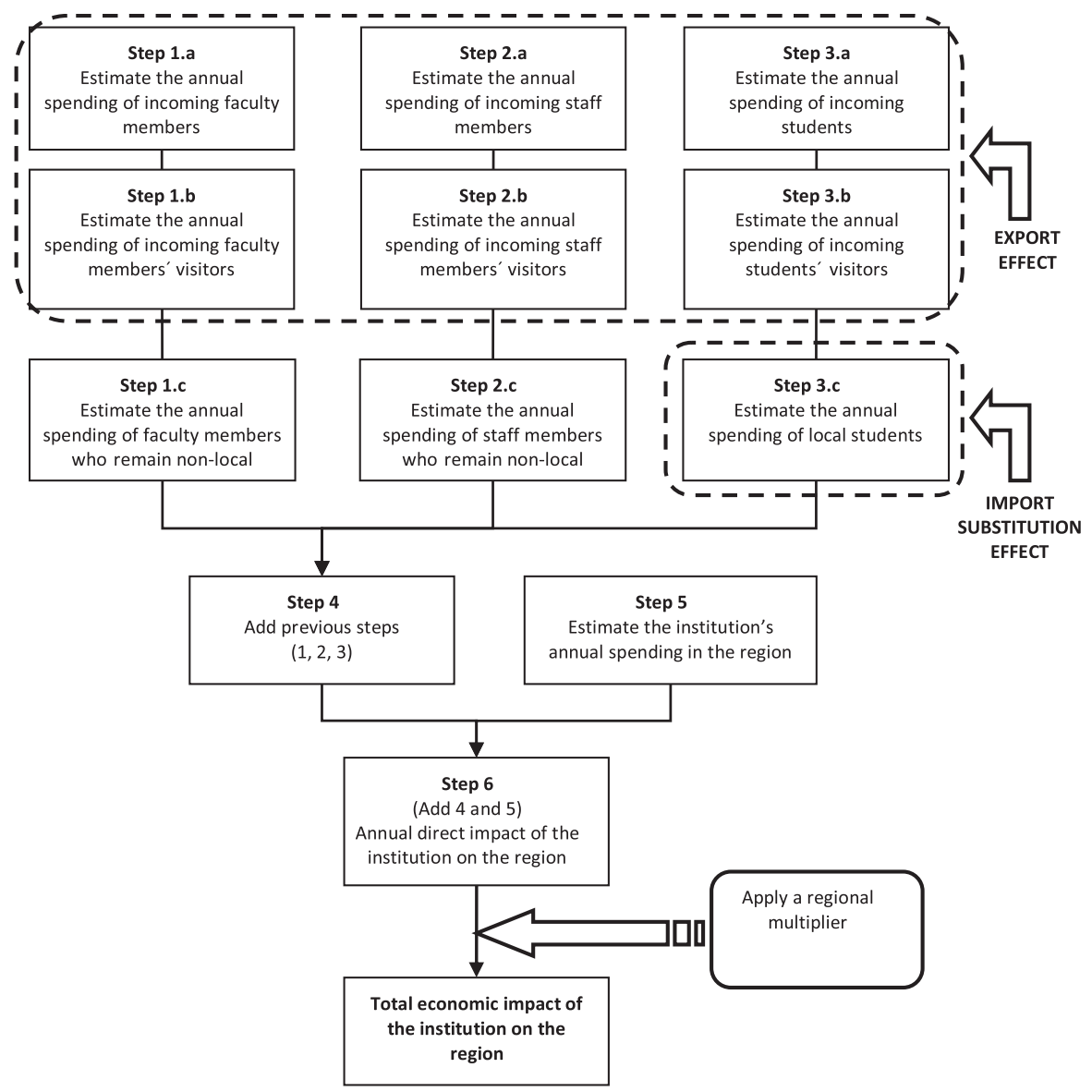

Figure 2. The economic impact model.

Source: Fernandes (2009, p. 198).

higher education institutions on the regions where they are located and enables a comparison between institutions/regions (the equations that define the model shown in Figure 2 can be provided by the authors).

\section{Methodology}

A methodological approach similar to the one adopted by Fernandes (2009) was followed in this study. Thus, the simplified model proposed required the surveying of students, faculty and staff, which was conducted between May and September 2012. An online questionnaire was developed based on the works of Buchanan (1994), Caffrey and Isaacs (1971), Martins, Mauritti, and Costa (2005), Seybert (2003) and Fernandes (2009). The final version of the questionnaires was the result of intensive discussions with representatives of the institutions participating in the study. 
The selected groups of individuals (i.e. faculty members, staff members and students) completed different surveys. For faculty members and staff members, the questionnaire consisted of three sections. The first related to their professional profile, and included information such as: academic position, college, years at the higher education institution, workload and assessment of the facilities. The second related to their personal and family background, including the following variables: gender, age, marital status, academic qualifications, home residence, current residence, number of people in their household and number of children. The final section dealt with living conditions (type of residence, monthly income, family monthly expenses, use of university restaurants, use of transport, visitors and respective stay durations, monthly savings, mortgages and investments).

The questionnaire administered to students consisted of six sections. The first collected their personal information (e.g. gender, age, nationality, marital status, home residence and current residence). The second addressed their educational background (e.g. qualifications, year of study, full/part-time student, college, first choice of studies, upper secondary degree and work experience). The third assessed their current academic situation (e.g. weekly number of classes, professional activity and study subject). The fourth was intended to assess living conditions (e.g. type of residence, characteristics of the residence, monthly budget, disaggregation of expenses, financial situation appraisal, use of canteens and restaurants, use of transport, visitors and respective stay durations). The fifth section described their family background (e.g. professional profile, educational level, monthly income of parents). The last section discussed the students' mobility (and included variables such as participation in student-exchange programmes and intentions regarding future settlement in the region after graduation).

To answer the questionnaire, for each higher education institution, a random sample of faculty members, staff members and students was selected. The number of questionnaires sent per institution was adjusted in accordance with the size of the polytechnic institute. Thus, the number of questionnaires sent to faculty members ranged between 80 and 120. With regard to staff members, the number of questionnaires was between 60 and 100. Lastly, the number of questionnaires administered to students ranged from 420 to 500 . The average response rate was about $50 \%$, ranging from $42.5 \%$ to $78.0 \%$ for faculty members, $35.0 \%$ to $66.7 \%$ for staff members and $29.2 \%$ to $69.2 \%$ for students.

The data collected allowed a full description of each higher education institution's staff and students from a social and family perspective, and were also able to thoroughly describe the spending of such individuals, as well as their investments, in order to understand their flow of funds originated. It was also necessary to collect data on the higher education institutions' spending from official records.

\section{Results}

Although the survey allowed for the collection of a large amount of data, which then enabled a fairly detailed socio-economic description of the different polytechnic institutes involved in this study, this paper focuses only on presenting a summary of the main results obtained regarding the economic dimension of those polytechnics' impact on the regions where they are located.

From the study, it was possible to estimate the range of spending and the average monthly household expenditures of the faculty and staff, which are summarized in Table 6. 
Table 6. Average monthly expenditures of the households of faculty and staff members.

\begin{tabular}{lcccrr}
\hline & \multicolumn{2}{c}{ Faculty } & & \multicolumn{2}{c}{ Staff } \\
\cline { 2 - 3 } \cline { 5 - 6 } Institute & Range $€$ & Mean $€$ & & Range $€$ & Mean $€$ \\
\hline Bragança & $1529-2769$ & 2029 & & $1166-1980$ & 1047 \\
Castelo Branco & $1420-2136$ & 1903 & & $1192-2573$ & 1479 \\
Leiria & $1379-3520$ & 1831 & & $1287-1771$ & 1596 \\
Portalegre & $1346-3245$ & 2149 & & $874-2891$ & 1287 \\
Setúbal & $1389-3927$ & 2211 & & $1140-1890$ & 1791 \\
Viana do Castelo & $1233-3676$ & 1826 & & $1106-2288$ & 1587 \\
Viseu & $1938-2738$ & 2193 & & $735-2820$ & 1818 \\
\hline
\end{tabular}

From the answers given to the questionnaires, it can be seen that the average spending of the faculty members' households ranged between $€ 1800$ and $€ 2200$, which for staff was between $€ 1000$ and $€ 1800$. The average age of the faculty and staff members ranges between 41 and 42 . With regard to the expenditure of students who moved to a different municipality to study, Table 7 presents a summary of the findings, as well as the percentage of students who went to study in a different part of the country to attend the polytechnic institute (export effect), and the percentage of students from the region who reported they would have moved to another region to study, if an institute had not existed in their own region (import substitution effect).

The average monthly spend of students who moved to the region to attend the polytechnic institute is ca. $€ 500$. The number of students who reported having moved to the region to study ranges between $14 \%$ and $64 \%$, for the Setúbal and Bragança polytechnic institutes, respectively, with a median percentage of about $40 \%$. The percentage of the export effect for polytechnics located in the inner regions of the country (which is generally higher than that of the coastal area) does not seem irrelevant. Figure 3 illustrates the relationship between the export effect and the population residing in the municipalities where the respective polytechnic is located. It appears that the polytechnics located in the inner regions have a much higher export effect than those located in the coastal area of the country. In this sense, the former contribute to attracting young people towards more deserted and ageing regions, potentially improving their fixation on those regions.

From Table 7, it can also be seen that, among students who reside in the region where the institute is located, the percentage of those who reported that they would study at another institution outside the region if the polytechnic did not exist, ranges between $30 \%$ and $60 \%$, for Portalegre and Setúbal, respectively. This dimension reinforces the youth fixation effect of polytechnics for the municipalities where they are located, which obviously impacts the life of these communities. This finding reinforces the role that the polytechnics located in rural areas play in promoting equality in access to higher education.

Table 8 presents a summary of the direct impact of each polytechnic institute within its region. From Table 8 , we can see that the highest direct impact was reported in Leiria (reaching approximately $€ 101 \times 10^{6}$ ) and that the lowest was reported in Portalegre $\left(€ 16 \times 10^{6}\right)$. These results are consistent with the observation that the direct impact's main component is related to student spending, representing, for most polytechnics, about $85 \%$ of the direct impact. 
Table 7. Average monthly expenditure of students and percentage of export and import effects.

\begin{tabular}{lccc}
\hline Institute & Monthly $(€)$ & Export effect (\%) & Import substitution effect (\%) \\
\hline Bragança & 496.8 & 63.7 & 53.3 \\
Castelo Branco & 428.6 & 43.2 & 47.8 \\
Leiria & 508.7 & 41.2 & 52.5 \\
Portalegre & 545.1 & 46.6 & 31.0 \\
Setúbal & 474.7 & 14.1 & 61.5 \\
Viana do Castelo & 476.5 & 36.9 & 54.0 \\
Viseu & 514.2 & 37.0 & 33.8 \\
\hline
\end{tabular}

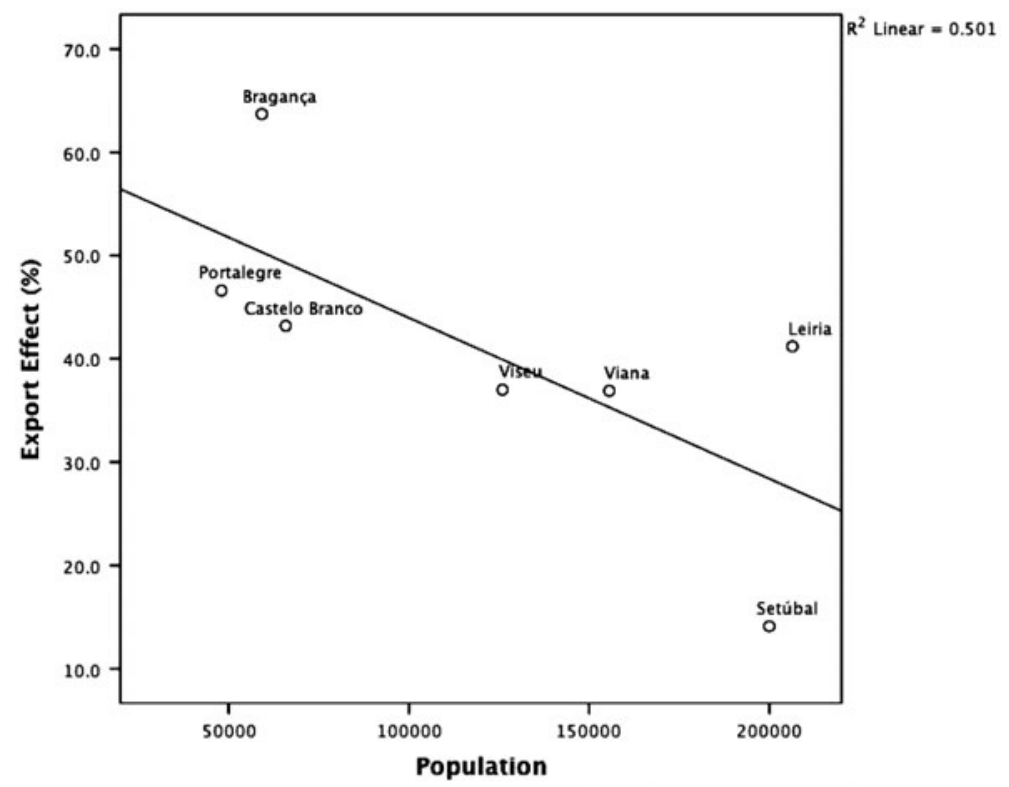

Figure 3. Relationship between the export effect and the resident population.

Table 8. Summary of the direct impact of each polytechnic institute.

\begin{tabular}{|c|c|c|c|c|c|c|c|}
\hline & $\begin{array}{l}\text { IP } \\
\text { Bragança }\end{array}$ & $\begin{array}{l}\text { IP Castelo } \\
\text { Branco }\end{array}$ & $\begin{array}{l}\text { IP } \\
\text { Leiria }\end{array}$ & $\begin{array}{l}\text { IP } \\
\text { Portalegre }\end{array}$ & $\begin{array}{l}\text { IP } \\
\text { Setúbal }\end{array}$ & $\begin{array}{l}\text { IP Viana do } \\
\text { Castelo }\end{array}$ & $\begin{array}{l}\text { IP } \\
\text { Viseu }\end{array}$ \\
\hline $\begin{array}{l}\text { (1) Faculty } \\
\text { spending }\end{array}$ & 4230 & 3823 & 9107 & 1545 & 3216 & 2283 & 3418 \\
\hline (2) Staff spending & 691 & 1041 & 1979 & 999 & 880 & 591 & 507 \\
\hline $\begin{array}{l}\text { (3) Students } \\
\text { spending }\end{array}$ & 33,264 & 15,401 & 86,607 & 13,060 & 27,678 & 16,060 & 35,660 \\
\hline $\begin{array}{l}\text { (4) Institution } \\
\text { spending }\end{array}$ & 789 & 763 & 3315 & 421 & 564 & 900 & 1304 \\
\hline $\begin{array}{l}\text { DIRECT } \\
\text { IMPACT } \\
(1+2+3+4)\end{array}$ & 38,974 & 21,028 & 101,008 & 16,025 & 32,339 & 19,835 & 40,890 \\
\hline
\end{tabular}

Note: Amounts in thousands of euros for the year 2012. 
If ordered by number of students, the group of polytechnics considered in this study would be as follows: Leiria, Bragança, Setúbal, Viseu, Castelo Branco, Viana do Castelo and Portalegre. The direct impacts feature a similar sequence. These figures constitute evidence of the existence of a linear relationship between the direct impact and the number of students attending each institution. Figure 4 shows the graph depicting the direct impact as a function of the number of students with a linear equation relating the two variables (direct impact $=-19,000+9300 \times$ number of students). We can see that, for each additional student, there is a direct annual impact of about $€ 9000$ which translates, in turn, into a total impact of about $€ 16,000$, by applying the multiplier selected (1.7).

Table 9 summarizes several indicators which attempt to illustrate the impact and relevance of the polytechnics under analysis in the regions where they are located.

From the analysis of Table 9, we may highlight the following results:

- The total impact in terms of economic activity generated results in an amount of $€ 27 \times 10^{6}$ for Portalegre and $€ 172 \times 10^{6}$ for Leiria, considering the value of the multiplier mentioned above (1.7).

- In terms of the relative weight on the gross domestic product (GDP) of all the municipalities where the respective polytechnics are located, the figures range from $1.71 \%$ for Setúbal to $11.02 \%$ for Bragança. It seems that this relative impact tends to be higher for polytechnics located in the municipalities of the inner regions of the country.

- The level of economic activity generated in the municipalities where the polytechnic is located, for every euro of funding received from the state budget, ranged from $€ 2.63$ in the case of Castelo Branco to $€ 8.07$ in the case of Leiria.

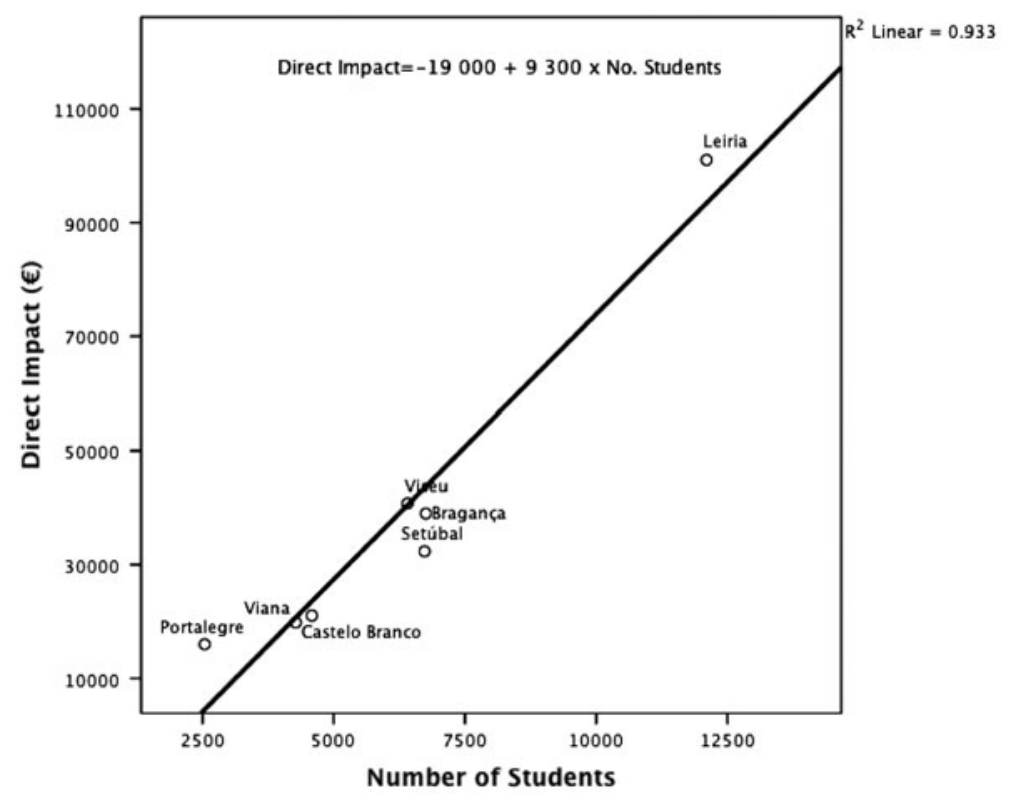

Figure 4. Relationship between the direct economic impact and the number of students attending the polytechnic institute. 


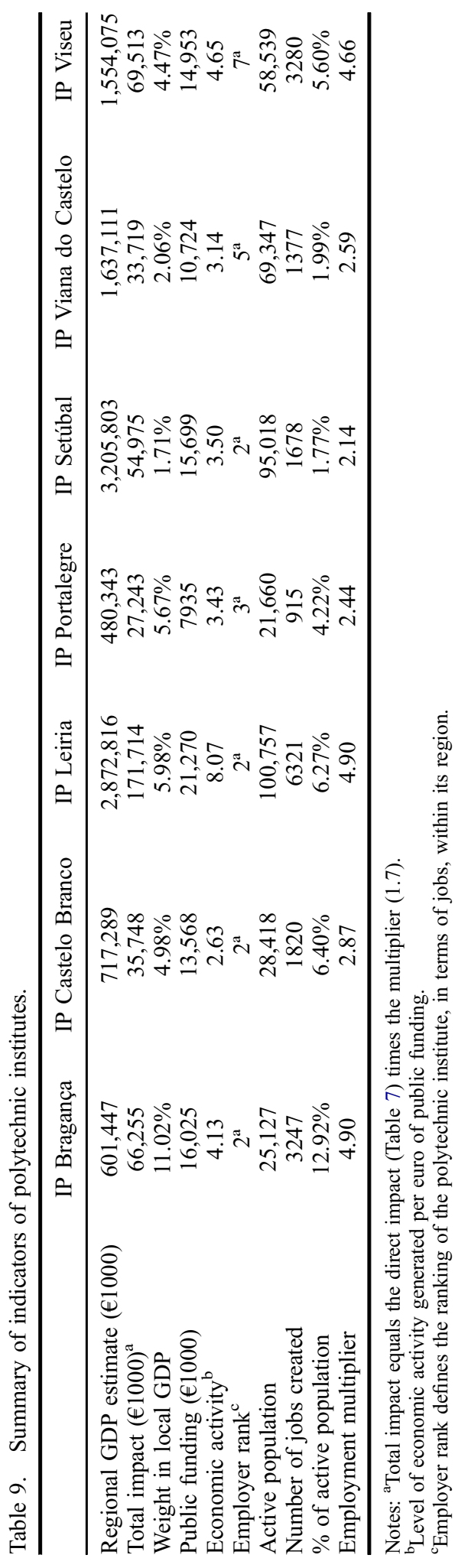


- Polytechnic institutes are major employers in the regions where they are located, ranking, in general, in second place.

- The estimated number of jobs created as a result of the location of the polytechnics in the region under analysis ranges from 915 in the case of Portalegre to 6321 in the case of Leiria. These figures were calculated based on the concept of apparent productivity of labour.

- The relative weight of the jobs created in terms of active population ranged from $1.77 \%$ in Setúbal to $12.92 \%$ in Bragança. It appears that this relative weight tends to be higher for polytechnics located in municipalities of the inner regions of the country.

- The multiplier obtained, associated with the number of jobs created, ranges from 2.14 in Setúbal to 4.9 in Bragança and Leiria.

\section{Discussion of the results}

From the group of polytechnics studied, Leiria clearly stands out from the others because of its size and consequent number of students. As we can see in Figure 4, the direct impact of the polytechnic of Leiria appears to be quite above those of the other polytechnics. A cluster analysis using the variables number of students, direct impact, weight on local GDP, public funding, economic activity generated and export effect shows the existence of three groups: one comprising only Leiria; another consisting of Bragança, Viseu and Setúbal; and, finally, a third cluster composed of Castelo Branco, Viana do Castelo and Portalegre. It seems, therefore, that the formation of clusters is significantly determined by the number of students and, consequently, the direct impact.

These results should, however, be interpreted while bearing in mind some limitations of the study itself. First, the low response rate of some groups of individuals in some institutions. Second, since there are no official data from the Statistics Institute for municipalities' GDP, these values had to be estimated. Third, a sensitive parameter of the model is the value of the multiplier used. Fourth, it was assumed that the sphere of influence of each polytechnic focused mainly on the municipalities where the schools of each polytechnic are located. While this approach may be limitative, it was justified by the difficulty in defining the geographical area of the study, particularly in regions located in metropolitan areas. Finally, the impact of higher education institutions on the formation of human capital was not taken into account, which probably causes the true impact of higher education institutions to be underestimated.

The findings of our study are in line with the results reported by Yserte and Rivera (2010), where the impact of the University of Alcalá, based on a simplified ACE model, represented $4.8 \%$ of the local GDP, with a multiplier effect on jobs created of 2.6 and an economic multiplier effect of 2.04. Pastor, Pérez, and Guevara (2013), on the other hand, referring to the five public universities of Valencia, Spain, found an impact of $3.6 \%$ on the community's GDP, with a multiplier on jobs generated of 2.39 , and an economic multiplier of 1.75 . It should be noted that the city of Alcalá de Henares has a population of 197,804 inhabitants (2005 data), whereas the Valencian Community has a population of 5.1 million inhabitants (2012 data).

A recent report on America's community colleges' economic impact (American Association of Community Colleges and Economic Modelling Specialist Intl., 2014) emphasizes that educational institutions, beyond their principal aim of education and training, provide external benefits that improve society as a whole, namely the 
improvement of the skills of the workforce, increased income, improved health, reduced employment, enhanced cultural activities and, consequently, improved social cohesion. Additionally, the presence of educational institutions tends to promote an increase in economic activity, inducing innovative activities, which require more skilled workers. Moreover, the report recognizes that the government funds allocated to educational institutions create positive social benefits that outweigh costs.

Similarly, Kelly, McNicoll, and White's (2014) report stresses 'the role of higher education in the economy and its potential contribution to supporting economic recovery and development' (p. 3). In this way, the higher education system is seen as a part of the economic infrastructure of the UK, stressing its role in the present economic recession. The report concludes that the impact of the higher education system is 'comparable in sectoral gross output terms to the advertising and market research industry and the legal services industry and larger than the basic pharmaceuticals sector' (p. 4). With regard to the direct multiplier effect, for every full-time job, 1.17 jobs are generated, and for every pound invested, $£ 1.35$ of output are generated in other sectors of the economy; lastly, in terms of GDP, the higher education system represented $2.8 \%$ of the UK's GDP in 2011.

\section{Conclusion}

This study, based on the simplified model developed by Fernandes (2009), allowed for a comprehensive and simultaneous analysis of the different realities of the seven polytechnics covered by the study. It is important to highlight the diversity of the institutions involved, both in terms of size and regional and socio-economic context.

It was possible to obtain an estimation of the impacts of the seven institutes in their respective regions. The impact on local GDP varied between $2 \%$ and $11 \%$, with a multiplier effect on job creation ranging from 2 to 5 . These results are highly significant, given that a conservative approach was followed in the assessment of the economic impact, in the sense that, essentially, only the impacts of individuals who had moved to the region were considered, taking into account the export and import substitution effects for students, faculty and staff. It is clear that the largest contribution to this impact resulted from the monthly spending of students who had moved to a particular region to study at the polytechnic institute. The results seem to substantiate a linear relationship between the value of the economic impact and the institutions' number of students. Finally, it is important to highlight the role of higher education institutions as major employers and, consequently, as fixators of qualified people in their respective regions.

It should be emphasized that the impact of polytechnic institutes goes far beyond the economic dimension, namely in aspects not easily quantifiable, such as sociocultural benefits and equality of access to higher education for these regions. In the future, the impact on the training and education of populations will be studied, following the approach proposed by Bluestone (1993), while trying to understand where graduates are, where they work, and what their incomes are. Future research will also address the effects of research and development activities and technology transfer, as well as the promotion of entrepreneurship.

Overall, the study allowed for the first quantified estimation of the economic impact of polytechnic institutes and its results clarified the importance of their public mission, particularly in terms of regional development, ensuring access to higher education and acting as transformation agents within the municipalities/regions where they are located. 
It is precisely this understanding of the many dimensions of their overall impact that makes local people appreciate the presence of polytechnics in their regions. They strengthen and assert the identity of those communities.

\section{Acknowledgements}

The authors of this work would like to thank the support provided by the Portuguese Polytechnics Coordinating Council (CCISP) and by the representatives of all polytechnic institutes involved in the study.

\section{References}

Agência de Avaliação e Acreditação do Ensino Superior [Portuguese Higher Education Evaluation Agency]. (2012). O Sistema de Ensino Superior em Portugal [Higher education system in Portugal]. Lisbon: Author.

American Association of Community Colleges and Economic Modeling Specialist Intl. (2014). Where value meets values: The economic impact of community colleges - Analysis of the economic impact and return on investment of education. Retrieved from http://www.economic modeling.com

Anton, P., \& Burns, A. (2007). The local economic impact of Minnesota State University, Mankato. Retrieved from http://www.wilder.org

Arbo, P., \& Benneworth, P. (2007). Understanding the regional contribution of higher education institutions: A literature review (OECD Education working paper 2007/09). Paris: OECD.

Becker, G. (1993). Human capital: A theoretical and practical analysis with special reference to education (3rd ed.). Chicago, IL: The University of Chicago Press.

Benneworth, P., Charles, D., Hodgson, C., \& Humphrey, L. (2013). The relationship of community engagement with universities' core missions. In P. Benneworth (Ed.), University engagement with socially excluded communities (pp. 85-101). Dordrecht: Springer.

Blackwell, M., Cobb, S., \& Weinberg, D. (2002). The economic impact of educational institutions: Issues and methodology. Economic Development Quarterly, 16, 88-95.

Bluestone, B. (1993, January). UMASS/Boston: An economic impact analysis (EDRS, HE 026 389, ED 356 733). Boston: University of Massachusetts.

Boucher, G., Conway, C., \& Van der Meer, E. (2003). Tiers of engagement by universities in their region's development. Regional Studies, 37, 887-897.

Brown, K., \& Heaney, M. (1997). A note on measuring the economic impact of institutions of higher education. Research in Higher Education, 38, 229-240.

Buchanan, D. (1994). The economic impact of Mississippi Valley State University on the local economy, 1992-93 (ED 384280 - HE 027 990). Itta Bena: Mississippi Valley State University.

Caffrey, J., \& Isaacs, H. (1971). Estimating the impact of a college or university on the local economy (ERIC ED 252100). Washington, DC: American Council on Education.

Caleiro, A., \& Rego, C. (2003). Impactes das instituições de ensino superior no território: estudo do caso da Universidade de Évora [Higher education impacts on the territory: The case study of the University of Évora] (Economic Working Papers No. 2-2003). Évora: Universidade de Évora.

Carr, R., \& Roessner, D. (2002, May). The economic impact of Michigan's public universities (SRI Project: PDH 02-019). Retrieved from http://www.michiganbusiness.org/cm/Files/ Reports/univimpactreport.pdf

Center for Higher Education Policy Studies. (2013, April). Policy challenges for the Portuguese polytechnic sector: A report for the Portuguese polytechnics coordinating council (CCISP) (C13JF026). Enschede: Author.

Charles, D. (2006). Universities as key knowledge infrastructures in regional innovation systems. Innovation: The European Journal of Social Science Research, 19, 117-130.

Charney, A., \& Pavlakovich-Kochi, V. (2003). University of Arizona research expenditures: Generating jobs, wages and tax revenues in the local economy. Tucson, AZ: Office of Economic Development, University of Arizona. 
Clarck, C., Feng, L., \& Stromsdorfer, E. (1998). The economic and social impact of Washington State University. Washington State University. Retrieved from http://www.wsu.edu/NIS/Eco nomicImpact.html

Drucker, J., \& Goldstein, H. (2007). Assessing the regional economic development impacts of universities: A review of current approaches. International Regional Science Review, 30, $1-27$.

Duhart, S. H. (2002, March). The economic impact of University System of Georgia institutions on their regional economies. Atlanta, GA: Intellectual Capital Partnership Program.

Elliott, D., Levin, S., \& Meisel, J. (1988). Measuring the economic impact of institutions of higher education. Research in Higher Education, 28, 17-33.

Emmett, R., \& Manaloor, V. (2000, May). Augustana University College and the Camrose AreaAn economic impact study. Retrieved from http://www.augustana.ab.ca

Etzkowitz, H., \& Leydesdorff, L. (2000). The dynamics of innovation: From national systems and "Mode 2" to a triple helix of university-industry-government relations. Research Policy, 29, $109-123$.

Fernandes, J. (2009). O impacto económico das instituições do ensino superior no desenvolvimento regional: o caso do Instituto Politécnico de Bragança [The economic impact of higher education institutions on regional development: The case of the Polytechnic Institute of Bragança]. Tese de Doutoramento [PhD Thesis], Escola de Engenharia da Universidade do Minho, Guimarães. Retrieved from http://repositorium.sdum.uminho.pt/handle/1822/10535

Fernandes, J., Cunha, J., \& Oliveira, P. (2013). The socioeconomic impact of an HEI for a local economy. In B. Boufoy-Bastick (Ed.), The international handbook of cultures of education policy (Vol. 1, pp. 557-575). Strasbourg: Analytics.

Healey, R., \& Akerblom, K. (2003, September). An economic partnership, Queen's University and the Kingston Area. Kingston: Office of Institutional Research and Planning.

Hermannsson, K., \& Swales, J. K. (2010, October). Capturing the overall economic impacts of HEIs. Glasgow: Department of Economics, University of Strathclyde.

Humphreys, J., \& Kamerschen, D. (2001). The economic impact of higher education: A case study in Georgia. The Mid-Atlantic Journal of Business, 37, 205-217.

Jefferson College. (2003, May 21). The economic impact of Jefferson College on the community and the State FY 2002. Hillsboro, MO: Office of Research and Planning. ERIC No. ED482799.

Johnson, T. (1994, November). Estimating the economic impact of a college or university on a nonlocal economy. Paper presented at the Annual Meeting of the Association for the Study of Higher Education (ASHE), Tucson, AZ. ERIC ED 375714. HE 027798.

Kelly, U., McNicoll, I., \& White, J. (2014). The impact of universities on the UK economy. London: Universities UK.

Langworthy, A. (2001, July). The economic impact of Swinburne University of Technology on the Shire of Yarra ranges (Final report). Melbourne: Swinburne University of Technology.

Lawton-Smith, H. (2003). Universities and local economic development: An appraisal of the issues and practices. Local Economy, 18, 2-6.

Livingston, G. (2001, August 21). The economic impact of the University of West Florida on the Northwest Florida economy. Pensacola, FL: Haas Center for Business Research and Economic Development, University of West Florida.

Macfarland, T. (1999, March). Guidelines on how to prepare an economic impact study of an American college or university using integrated postsecondary education data system (IPEDS) survey data. Boca Raton, FL: Author.

Macfarland, T. (2001, May). An estimate of Nova Southeastern University's economic impact on South Florida and Florida for fiscal year 2000. Fort Lauderdale, FL: Nova Southeastern University Research and Planning, Report 01-08.

Martins, S., Mauritti, R., \& Costa, A. (2005). Condições socioeconómicas dos estudantes do ensino superior em Portugal [Higher education students' socioeconomic conditions in Portugal] (5th ed.). Lisboa: Ministério da Ciência, Tecnologia e Ensino Superior, Colecção Temas e Estudos de Acção Social [Ministry of Science and Technology and Higher Education].

McNicoll, I., McCluskey, K., \& Kelly, U. (1997). The impact of universities and colleges on the UK economy. London: British Library Document Supply Centre-DSC: 99/32580. 
Miller, W. (1994). Economic multipliers: How communities can use them for planning. Fayetteville: University of Arkansas, Division of Agriculture, Cooperative Extension Work, Acts of May 8 and June 30 1994, FSCDD6-PD-7-04R.

Mueller, P. (2005, August 23-27). Exploring the knowledge filter: How entrepreneurship and university-industry relations drive economic growth. Paper presented at the 45th Congress of the European Regional Science Association - "Land Use and Water Management in a Sustainable Network Society", Amsterdam.

Nagowski, M. (2006). Assessing the economic impact of higher education institutions in New England. New England Public Policy Center. Retrieved from http://www.bos.frb.org/eco nomic/neppc

Ohme, A. (2004). The economic impact of a university on its community and state: Examining trends four years later. Newark: University of Delaware, Office of Institutional Research and Planning.

Organisation for Economic Co-operation and Development (OECD). (2008). Education at a glance 2008: OECD indicators. Paris: Author. Retrieved from http://www.oecd.org/dataoecd/ 23/46/41284038.pdf

Organisation for Economic Co-operation and Development (OECD). (2012). Education at a glance 2012: OECD indicators. Paris: Author. Retrieved from http://dx.doi.org/10.1787/eag2012-en

Pastor, J., Pérez, F., \& Guevara, J. (2013). Measuring the local economic impact of universities: An approach that considers uncertainty. Higher Education, 65, 539-564.

Pinheiro, R., Benneworth, P., \& Jones, G. A. (2012). Understanding regions and the institutionalization of universities. In R. Pinheiro, P. Benneworth, \& G. Jones (Eds.), Universities and regional development: A critical assessment of tensions and contradictions (pp. 11-32). New York, NY: Routledge.

Rephann, T. J., Knapp, J. L., \& Shobe, W. M. (2009). Study of the economic impact of Virginia public higher education. Charlottesville, VA: Weldon Cooper Center for Public Service, University of Virginia.

Ryan, G., \& Malgieri, P. (1992). Economic impact studies in community colleges: The short cut method (ED 469 387, JC 020 682). Washington, DC: National Council for Resource Development.

Seybert, J. (2003). The economic impact of Barton County Community College on its service area 2001-2002. Overland Park, KS: Office of Institutional Research, Johnson County Community College.

Siegfried, J., Sanderson, A., \& McHenry, P. (2007). The economic impact of colleges and universities. Economics of Education Review, 26, 546-558.

Smith, B. (2006). The economic impact of higher education on Houston: A case study of the University of Houston system. University of Houston Institute for Regional Forecasting. Retrieved from http://www.advancement.uh.edu

Sudmant, W. (2002, November). The economic impact of the University of British Columbia on the Great Vancouver Regional District. Vancouver, BC: Planning and Institutional Research, Uiversity of British Columbia.

University of Strathclyde. (2006, March). The economic impact of UK higher education institutions. Universities UK. Retrieved from http://www.universitiesuk.ac.uk

Weisbrod, G., \& Weisbrod, B. (1997). Measuring economic impacts of projects and programs. Boston, MA: Economic Development Research Group.

Yserte, R., \& Rivera, M. (2010). The impact of the university upon local economy: Three methods to estimate demand-side effects. The Annals of Regional Science, 44, 39-67. 